\title{
Deteksi Kebohongan Berdasarkan Fitur Fonetik Akustik
}

\author{
Anang Kusnadi ${ }^{1}$, I Made Oka Widyantara ${ }^{2}$ Linawati $^{3}$
}

[Submission: 15-02-2021, Accepted: 08-03-2021]

\begin{abstract}
This study aims to statistically analyze the parameters of acoustic phonetic features, namely: pitch, formant and intensity as indicators of psychological pressure from a person's lying or honest voice. Voice samples are the answers to "No" to the relevant and comparison questions on the examined subjects on the polygraph test. The Praat software was used for feature extraction and data analysis using SPSS with the T Paired Test and the Wilcoxon Test. Based on the results of the statistical analysis of acoustic phonetic features, a scoring system is proposed by setting a score (+1) when the results of Ho's statistical analysis are accepted (Sig > 0.05) or in other words there is no difference between the formant, intensity and pitch values of the answer to "no" to the relevant and the comparison questions. And vice versa set a score (-1) when the results of statistical analysis Ho is rejected (Sig $<0.05)$ or in other words there are differences in the value of formant, intensity and pitch of the answer to "no" to the relevant and the comparison questions. The final conclusion is that the total score (+) indicates honest and the total score (-) indicates a lie.
\end{abstract}

Keyword : Lie Detector, Poligraph, Formant, Pitch, Intensity, Pratt, SPSS.

Intisari - Penelitian ini bertujuan menganalisis secara statistik parameter fitur fonetik akustik yaitu : pitch, formant dan intensity sebagai indikator tekanan psikologis dari suara berbohong atau jujur seseorang. Sampel suara adalah jawaban "Tidak" pertanyaan relevant dan comparison subyek terperiksa yang ada pada tes poligraf. Perangkat lunak Praat digunakan untuk ekstraksi fitur dan analisis datanya menggunakan SPSS dengan Uji T Paired dan Uji Wilcoxon. Berdasarkan hasil analisis statistik fitur fonetik akustik diusulkan sistem scoring dengan menetapkan skor (+1) ketika hasil analisis statistik Ho diterima $(\mathrm{Sig}>0,05)$ atau dengan kata lain tidak ada perbedaan antara nilai formant, intensity dan pitch jawaban "tidak" pertanyaan comparison dan relevant. Dan sebaliknya menetapkan skor (-1) ketika hasil analisis statistik Ho ditolak $($ Sig $<0,05)$ atau dengan kata lain ada perbedaan nilai formant, intensity dan pitch jawaban "tidak" pertanyaan comparison dan relevant. Kesimpulan akhir adalah skor total $(+)$ terindikasi jujur dan skor total (-) terindikasi bohong.

Kata kunci: Deteksi Kebohongan, Poligraf, Formant, Pitch, Intensity, Pratt, SPSS.

\section{PENDAHULUAN}

${ }^{1}$ Kasubbid, Subbid Fiskom, Bidlabfor Polda Bali, Jl. Gunung Sangiang no. 108 B Denpasar (80117), dan Mahasiswa, Program Pasca Sarjana, Magister Teknik Elektro, Universitas Udayana (email: anangks@gmail.com)

2, 3 Dosen, Program Studi Magister Teknik Elektro, Fakultas Teknik, Universitas Udayana, Jln. Jalan Kampus Bukit Jimbaran 80361 INDONESIA (telp: 0361-703315; fax: 0361-4321; e-mail: oka.widyantara@unud.ac.id, linawati@unud.ac.id.
Berbohong atau menipu merupakan sifat menutupi keadaan yang sebenarnya. Penipuan dan deteksinya berhubungan dengan perilaku psikologi yang rumit berkaitan dengan proses kognitif dan aktivitas mental [1]. Suatu yang alamiah bahwa manusia cenderung melakukan kebohongan di saat mereka melakukan perbuatan yang salah serta memiliki kecenderungan untuk menghindar dan menutup diri dari orang lain. Terlebih ketika dia sadar akan konsekuensi yang akan ditanggung, seperti menanggung malu dan juga bila dirinya terancam akan dijatuhi hukuman kurungan, tentu orang tersebut semakin bertahan untuk berbohong.

Dewasa ini orang telah banyak tertarik melakukan penelitian tentang bagaimana untuk mendeteksi kebohongan secara akurat. Mayoritas penelitian tentang deteksi kebohongan sebelumnya telah dilakukan oleh banyak peneliti yang sebagian besar tertarik pada aspek non verbal seperti pencitraan otak [2], [3], [4] ; tatapan mata [5], [6]; ekspresi mikro wajah [7], [8]; gerakan beban kognitif [9]; gestur tubuh [10] dan poligraf [11], [12], [13]. Penelitian ini tentu sangat bermanfaat untuk semua bidang dan implementasinya secara riil dapat disebutkan antara lain: untuk screening pegawai baru, untuk menganalisis calon nasabah bank, untuk introgasi pada dunia militer dan untuk membantu penyidikan petugas penegak hukum dalam pengungkapan suatu kasus pidana, dsb.

Sebagian peneliti lainnya tertarik pada aspek verbal (analisis suara). Beberapa diantaranya sudah menggunakan algoritma otomatis dan dipasarkan secara komersial seperti VSA (Voice Stress Analyser) dan LVA (Layered Voice Analysis). Namun demikian baik VSA maupun LVA telah mengalami uji validitas dan reliabilitas, hasilnya tidak cukup handal dan kurang memuaskan [14], [15], [16], [17]. Peneliti lainnya tertarik melakukan investigasi fitur akustik untuk mendeteksi kebohongan yaitu pada [18] mengeksplorasi perubahan dalam sinyal suara ketika sesorang menipu. Sampel ucapan dianalisis pada berbagai parameter akustik dan temporal, hasilnya menunjukkan korelasi tidak signifikan yang disajikan pada parameter $\mathrm{f}_{0}$, intensity dan frekuensi vokal formant. Berikutnya pada [19] peneliti berusaha mengidentifikasi fonetik akustik mana yang dapat digunakan sebagai indikator stress yang dapat diandalkan karena penipuan dengan menganalisis parameter akustik seperti pitch, formant, jitter dan shimmer. Hasil penelitian adalah bahwa mean pitch dan frekuensi formant F1, F2 berkorelasi kuat terhadap stress penipuan. Terdapat perbedaan hasil dari kedua penelitian di atas dan ini mungkin disebabkan oleh beban kognitif dan atau tingkat stress yang diterima oleh subyek terperiksa yang berkata bohong sangat berbeda. Sebagai catatan pada [18] menggunakan paradigma mock yaitu kebohongan yang diskenariokan sedangkan [19] dalam penelitiannya menganalisis kebohongan nyata ketika 
seseorang ingkar atas tuduhan perbuatan kriminal terhadap dirinya.

Akhirnya kami tertarik menggunakan analisis fonetik akustik sebagai petunjuk perkataan berbohong atau jujur dari tingkat tekanan psikologis (stress) melanjutkan penelitian sebelumnya [18] dan [19], terutama karena dalam pengamatan kami di bidang ini masih minim penelitian dalam kurun waktu 5 tahun terakhir dan adanya perbedaan hasil pada kedua penelitian tersebut. Pada penelitian ini penulis menggunakan paradigma mock seperti yang dilakukan [18]. Kekuatan penelitian ini menggunakan model "true eksperimental" dan melakukan penilaian suara berbohong atau jujur seseorang secara real time pararel dengan tes poligraf (Polygraph). Kombinasi 2 teknik deteksi kebohongan ini diharapkan mampu meningkatkan probabilitas mengidentifikasi dengan benar seseorang yang berbohong atau menipu [16].

\section{POLIGRAF}

Sistem atau alat untuk mendeteksi kebohongan melalui isyarat non verbal yang paling popular adalah "Psychophysiological Detection of Deception (PDD) Systems" dikenal dengan nama "Poligraf" atau "Lie Detector" [13]. Prinsipnya adalah mendeteksi seseorang yang berbohong berdasarkan perubahan reaksi fisiologis tubuhnya ketika mendapat tekanan secara psikologis dalam usahanya menutupi kebohongan. Sebagai alat deteksi kebohongan Poligraf memang dikenal yang paling mapan dan matang, tetapi poligraf dianggap sedikit intrusive dan invasive. Tetapi kekurangan ini tidak mengurangi penilaian terhadap poligraf sebagai alat deteksi kebohongan yang terbaik sampai saat ini. Forensic Research, Inc. mengulas 80 proyek penelitian yang dipublikasikan sejak tahun 1980 yang melibatkan lebih dari 6,380 pemeriksaan poligraf dengan tujuan mengetahui validitas dan reliabilitas dari Poligraf. Hasilnya, tes Poligraf rata-rata akurasinya adalah 98\% [14]. Di luar Poligraf, metode deteksi kebohongan non verbal seperti : analisis tatapan mata, ekspresi wajah dan gerakan tubuh kurang dapat diandalkan [1].

\section{DETEKSI KEBOHONGAN BERDASARKAN FITUR FONETIK AKUSTIK}

Suara manusia bisa menjadi tanda keadaan psikologis seseorang, baik sadar ataupun tidak sadar dapat mengungkapkan keadaan internal pembicara. Dari setiap bunyi yang dihasilkan akan dianalisis fitur akustik fonetiknya yang terdiri dari fitur formant, intensity dan pitch secara off line menggunakan perangkat lunak pratt. Data fitur-fitur tersebut selanjutnya akan dianalisis secara statistik menggunakan SPSS (Statistical Product and Service Solutions) dengan uji beda menggunakan Uji T Paired untuk data yang berdistribusi normal dan Uji Wilcoxon untuk data yang berdistribusi tidak normal.

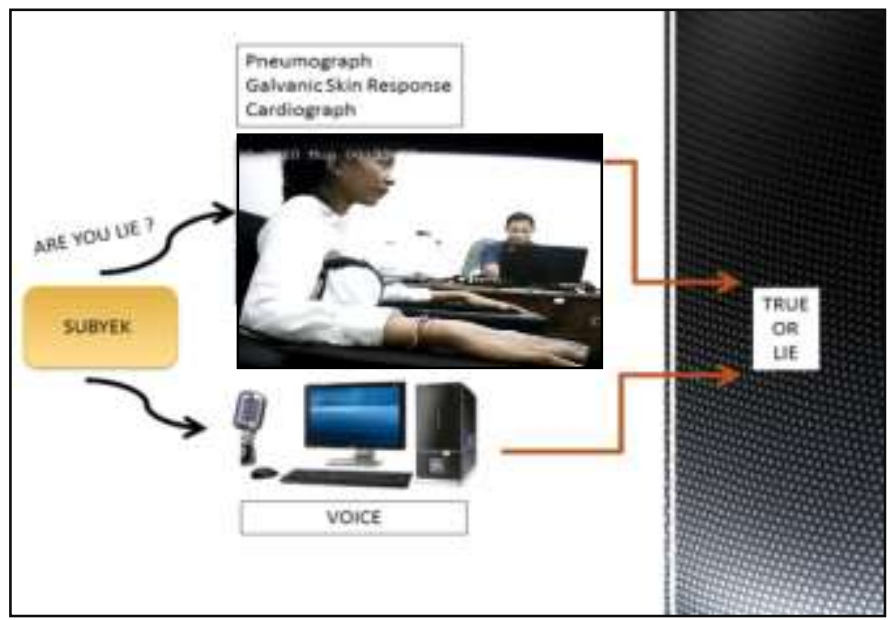

Gambar 1: Overall Penelitian

Tujuan utama dari penelitian ini adalah menganalisis secara statistik fitur fonetik akustik mana yang dapat digunakan sebagai indikator tekanan psikologis (stress) untuk mengidentifikasi suara berbohong atau jujur seseorang. State of the art review pada penelitian ini adalah membuat sistem penilaian (scoring) deteksi kebohongan berdasarkan fitur fonetik akustik. Hal ini belum pernah dikerjakan oleh peneliti lain.

\section{METODE PENELITIAN}

Penelitian ini menggunakan metode eksperimental. Penelitian eksperimental adalah penelitian yang dilakukan dengan membuat manipulasi terhadap subyek penelitian serta tersedianya kontrol [20]. Skema penelitian ini adalah melakukan kombinasi terhadap 2 teknik PDD (Psycophysiological Detection of Deception) dengan harapan mampu meningkatkan probabilitas mengidentifikasi dengan benar seseorang yang berbohong atau menipu melalui suaranya. Teknik PDD yang pertama adalah tes kebohongan berbasis suara sebagai inti penelitian dan yang kedua adalah tes poligraf sebagai pembanding.

\subsection{Pemeriksaan poligraf}

Pada masing-masing chart pemeriksaan poligraf dilakukan scoring oleh 3 (tiga) pemeriksa poligraf. Disini reaksi tubuh dari pertanyaan relevant $(\mathrm{R})$ dibandingkan dengan pertanyaan comparison (C). Kriteria penilaian dalam penelitian ini menggunakan tiga posisi scoring (3 skala) untuk pneumo (lihat grafik warna biru), EDA (lihat grafik warna hijau) dan cardio/blood pressure (lihat grafik warna merah) (Lihat pada gambar 2). Skala 3 posisi hanya membolehkan satu dari tiga nilai untuk analisis spot: $(-1),(0)$ atau $(+1)$. Skala 3 posisi menetapkan skor (-) ketika reaksi terbesar ada pada pertanyaan relevant, menetapkan skor $(+)$ ketika reaksi terbesar ada pada pertanyaan comparison dan menetapkan skor (0) jika tidak ada perbedaan reaksi (lihat gambar 3). 


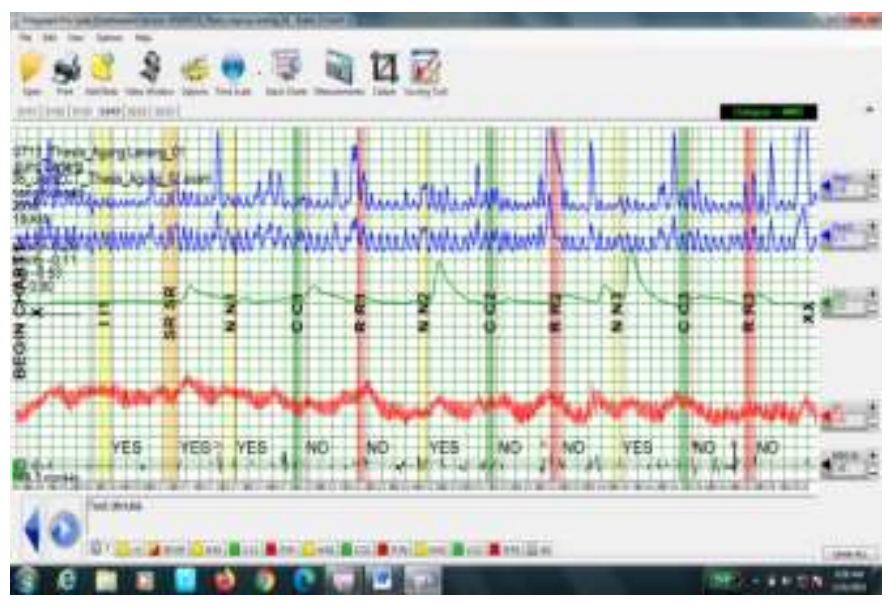

Gambar 2: Contoh grafik hasil pemeriksaan poligraf subyek Ag Chart 1

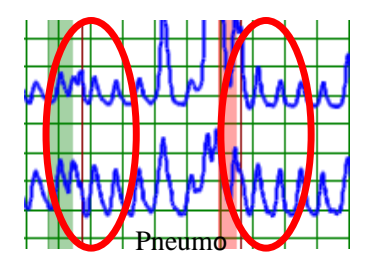

$\mathrm{C}=\mathrm{R}$ maka nilai adalah 0

$\mathrm{C}<\mathrm{R}$ maka nilai adalah -1

C > R maka nilai adalah 1
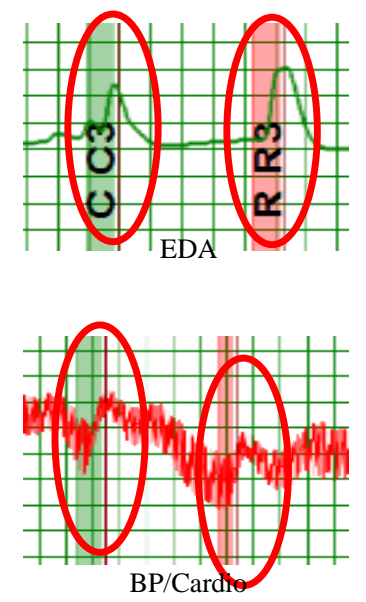

Gambar 3: Kriteria penilaian grafik poligraf menggunakan tiga posisi scoring (3 skala)

Kemudian untuk scoring adalah menggunakan ESS ZCT EXAMS (3R). Metode ESS (Empirical Scoring System) ini banyak digunakan karena probabilitas kesalahan (probability error) yang relatif rendah sekitar 0,001 [21]. Total score adalah total dari masing-masing variabel yaitu Pneumo, EDA dan Cardio/BP adalah kurang atau sama dengan -4, dan kriteria nilai No Deception Indicated (tidak bohong) adalah lebih atau sama dengan +2 , sedangkan diantara kedua kriteria tersebut adalah inconclusive/no opinion (tidak dapat disimpulkan).

1. Total score $\leq-4$ adalah DI (Deception Indicated / bohong). Anang Kusnadi: Deteksi Kebohongan berdasarkan Fitur Fonetik ...
2. Total score $\geq+2$ adalah NDI (No Deception Indicated / tidak bohong).

3. All else is NO (No Opinion / Inconclusive / tidak dapat disimpulkan).

Sebagai catatan jika hasilnya inconclusive/no opinion, apabila sub total $\leq-7$, maka Deception Indicated (bohong).

\subsection{Pemeriksaan sampel suara}

Pemeriksaan sampel suara dibagi menjadi tiga tahapan, yaitu 1) Mekanisme produksi suara, 2) Analisis statistik fonetik akustik, dan 3) Penilaian (scoring). Mekanisme produksi suara dilakukan dengan tujuan untuk memperoleh sampel suara. Analisis statistik fonetik akustik dilakukan untuk mengolah dan mengidentifikasi fitur-fitur akustik yang terdapat dalam kontur suara, sedangkan scoring dilakukan dengan tujuan untuk memberikan evaluasi terhadap subyek dalam bentuk nilai berdasarkan hasil tes uji. Untuk subyek dari kasus dugaan tindak pidana nyata otomatis tekanan psikogisnya bersifat nyata, alami dan tinggi, lain halnya dengan subyek yang diminta bersandiwara untuk melakukan kebohongan tentunya tingkat stressnya menjadi lebih rendah.

Penelitian ini membutuhkan sampel suara subyek dengan kondisi tekanan psikologis mirip orang yang berbohong secara alami, sehingga peneliti menganggap bagian ini merupakan tantangan terbesar penelitian. Oleh karena itu diperlukan mekanisme produksi suara yang tepat agar dapat tercapai tujuan penelitian. Skenarionya adalah dengan menempatkan 1 pasangan terdiri dari 2 subyek dalam suatu ruangan. Salah satu subyek diinstruksikan untuk mengambil dan menyembunyikan uang yang ada di dalam sebuah dompet yang terletak di atas meja. Diasumsikan subyek yang mengambil uang tidak mengakui perbuatannya atau berbohong tidak mengambil uang dimaksud. Skenario ini akan dilakukan terhadap 6 subyek (3 pasangan), karena metode pengumpulan datanya yang bersumber pada pemeriksaan tes poligraf mulai dari pre test (observasi subyek dan wawancara), In-test, Test Data Analysis dan Post-test yang tentu saja memerlukan durasi waktu yang cukup lama sehingga tidak dimungkinkan untuk mengambil sampel yang terlalu banyak. Disarankan penelitian eksperimen setidaknya menggunakan ukuran sampel minimal 5, untuk kemudahan menghitung nilai rata-rata dan standar deviasinya [22].

Penelitian ini memanfaatkan data suara tak spontan atau terencana yang ditimbulkan oleh pertanyaan dan kondisi yang dapat membangkitkan stimulus berupa tekanan psikologis terhadap orang yang berbohong atau menipu. Jadi nantinya akan ada 2 kelompok, kelompak pertama adalah kelompok treatment yaitu kelompok subyek yang diberi pertanyaan dengan kondisi adanya tekanan psikologis, dimana subyek tidak mengakui perbuatannya atau berbohong tidak mengambil uang dimaksud, dan kelompok kedua adalah kelompok control yaitu kelompok subyek yang diberi pertanyaan dengan kondisi tanpa adanya tekanan psikologis, dimana subyek jujur atau tidak berbohong tidak mengambil uang dimaksud.

Dari skenario di atas peneliti membuat model mekanisme p-ISSN:1693 - 2951; e-ISSN: 2503-2372 
produksi suara, yaitu mengambil sampel suara secara real time pararel dengan tes poligraf terhadap kedua subyek dalam setiap pasangan. Data suara tidak spontan pada penelitian ini terdiri dari jawaban "tidak" dari subyek ketika diberikan 2 jenis pertanyaan yang dapat membangkitkan reaksi tubuh (relevant dan comparison). Formulasi pertanyaan relevant dan comparison ini adalah jenis pertanyaan yang ada pada tes poligraf. Adapun hasil yang diharapkan adalah sesuai hipotesis bahwa reaksi tubuh pada pertanyaan relevant lebih reaktif dari pertanyaan comparison terindikasi bohong.

Tahap selanjutnya adalah melakukan analisis statistik terhadap fitur fonetik akustik yang merupakan tahapan dominan dalam uji deteksi kebohongan berbasis suara. Metode analisis statistik secara lengkap adalah berikut ini.

1. Perumusan masalah

Apakah ada perbedaan nilai fitur fonetik akustik (formant, intensity dan pitch) pada jawaban kata "tidak" jika ia diberi pertanyaan comparison dengan ia diberi pertanyaan relevant?

2. Hipotesis
a. $\mathrm{H}_{0}$ : Tidak ada perbedaan nilai fitur fonetik akustik jawaban kata "tidak" jika ia diberi pertanyaan comparison dengan ia diberi pertanyaan relevant.
b. $\mathrm{H}_{1}$ : Ada perbedaan nilai fitur fonetik akustik jawaban kata "tidak" jika ia diberi pertanyaan comparison dengan ia diberi pertanyaan relevant.

3. Pengambilan keputusan dengan menggunakan probabilitas/nilai signifikan.

a. Jika Sig > 0,05 maka $\mathrm{H}_{0}$ diterima.

Artinya tidak ada perbedaan nilai fitur fonetik akustik jawaban kata "tidak" jika ia diberi pertanyaan comparison dengan ia diberi pertanyaan relevant (indikasi jujur)

b. Jika Sig $<0,05$ maka $\mathrm{H}_{0}$ ditolak.

Artinya ada perbedaan nilai fitur fonetik akustik jawaban kata "tidak" jika ia diberi pertanyaan comparison dengan ia diberi pertanyaan relevant, (indikasi bohong).

Berikutnya adalah melakukan penilaian (scoring) terhadap subyek sebagai tahapan akhir dan dasar pengambilan keputusan dari uji deteksi kebohongan berbasis suara. Scoring ini merujuk pada scoring polygraph "Bigger is better", yang menurut penulis sudah teruji, dimana reaksi terbesar mengindikasikan rangsangan yang lebih yang merupakan wujud pertahanan diri.

Usulan penulis adalah melakukan scoring terhadap hasil analisis statistik fitur fonetik akustik pada pertanyaan relevant dan comparison dengan menetapkan skor $(+1)$ ketika hasil analisis statistik Ho diterima (Sig > 0,05) atau dengan kata lain tidak ada perbedaan nilai formant, intensity dan pitch jawaban kata "tidak" pertanyaan comparison dengan jawaban kata "tidak" pertanyaan relevant. Demikian sebaliknya menetapkan skor (-1) ketika hasil analisis statistik Ho ditolak $($ Sig $<0,05)$ atau dengan kata lain ada perbedaan nilai formant, intensity dan pitch jawaban kata "tidak" pertanyaan comparison dengan jawaban kata "tidak" pertanyaan relevant.
Kesimpulan akhir adalah skor total (+) terindikasi jujur dan skor total (-) terindikasi bohong.

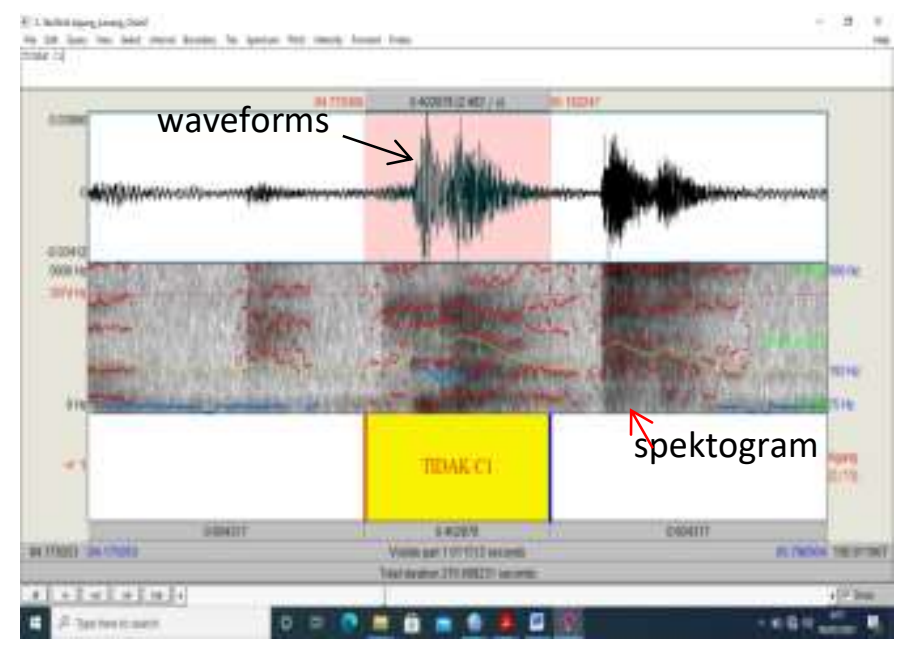

Gambar 4. Waveforms, spectogram, formant, intensity dan pitch sampel Ag Chart $1 \mathrm{C} 1$.

Lihat pada gambar 4 di dalam baris tengah, tampak grafik warna merah menunjukkan formant, warna kuning menunjukkan intensity dan warna biru menunjukkan pitch.

\section{HASIL DAN PEMBAHASAN}

\subsection{Hasil Pemeriksaan Poligraf}

Hasil tes poligraf keseluruhan subyek terperiksa dapat dilihat pada tabel-tabel dibawah ini.

TABEL I

HASIL SCORING POLIGRAF SUBYEK AG

\begin{tabular}{rlrrrr}
\hline \multicolumn{2}{c}{$\begin{array}{c}\text { Grafik } \\
\text { Reaksi Tubuh }\end{array}$} & R1 & R2 & R3 & Total \\
\hline Chart 1 & Pneumo & 0 & 0 & 0 & 0 \\
& Eda & 2 & 0 & -2 & 0 \\
& Cardio/BP & 1 & 0 & 1 & 2 \\
& Sub Total & 3 & 0 & -1 & 2 \\
\multirow{5}{*}{ Chart 2 } & Pneumo & -1 & 0 & 0 & -1 \\
& Eda & 2 & -2 & 2 & 2 \\
& Cardio/BP & 1 & -1 & 1 & 1 \\
& Sub Total & 2 & -3 & 3 & 2 \\
Chart 3 & Pneumo & & & & \\
& Eda & 0 & 1 & 0 & 1 \\
& Cardio/BP & -2 & -2 & 2 & -2 \\
& Sub Total & 0 & -1 & 1 & 0 \\
Total 3 Chart & -2 & -2 & 3 & -1 \\
& & 3 & -5 & 5 & 3
\end{tabular}

TABEL II

HASIL SCORING POLIGRAF SUBYEK YOG

\begin{tabular}{llrrrr}
\hline \multicolumn{2}{c}{$\begin{array}{c}\text { Grafik } \\
\text { Reaksi Tubuh }\end{array}$} & R1 & R2 & R3 & Total \\
\hline Chart 1 & Pneumo & 0 & 0 & 0 & 0 \\
& EDA & 0 & 2 & 0 & 2 \\
& Cardio/BP & 1 & -1 & 1 & 1 \\
& Sub Total & 1 & 1 & 1 & 3 \\
Chart 2 & Pneumo & 0 & 0 & 0 & 0 \\
\hline
\end{tabular}




\begin{tabular}{llrrrr}
\hline \multirow{5}{*}{ Chart 3} & EDA & 0 & 2 & 0 & 2 \\
& Cardio/BP & -1 & -1 & -1 & -3 \\
& Sub Total & -1 & 1 & -1 & -1 \\
& Pneumo & 0 & 0 & 0 & 0 \\
& EDA & 2 & 0 & 2 & 4 \\
& Cardio/BP & 1 & 0 & -1 & 0 \\
& Sub Total & 3 & 0 & 1 & 4
\end{tabular}

\begin{tabular}{llrrrr}
\hline \multirow{5}{*}{ Chart 3 } & EDA & -2 & 2 & -2 & -2 \\
& Cardio/BP & 0 & 1 & -1 & 0 \\
& Sub Total & -2 & 4 & -3 & -1 \\
& Pneumo & 0 & 0 & 1 & 1 \\
& EDA & 2 & 2 & 0 & 4 \\
& Cardio/BP & 1 & -1 & 1 & 1 \\
Sub Total & 3 & 1 & 2 & 6 \\
\multicolumn{1}{c}{ Total 3 Chart } & 5 & 2 & -2 & 5 \\
\hline
\end{tabular}

$\underline{\text { Total } 3 \text { Chart }}$ 3 2 1 6

TABEL III

HASIL SCORING POLIGRAF SUBYEK ERK

\begin{tabular}{llrrrr}
\hline \multicolumn{2}{c}{$\begin{array}{c}\text { Grafik } \\
\text { Reaksi Tubuh }\end{array}$} & R1 & R2 & R3 & Total \\
\hline Chart 1 & Pneumo & 1 & 1 & 0 & 2 \\
& EDA & 2 & 2 & 2 & 6 \\
& Cardio/BP & 1 & 1 & -1 & 1 \\
& Sub Total & 4 & 4 & 1 & 9 \\
Chart 2 & Pneumo & 0 & -1 & 1 & 0 \\
& EDA & -2 & -2 & -2 & -6 \\
& Cardio/BP & 1 & 1 & 1 & 3 \\
& Sub Total & -1 & -2 & 0 & -3 \\
\multirow{5}{*}{ Chart 3} & Pneumo & & & & \\
& EDA & 0 & 0 & 0 & 0 \\
& Cardio/BP & 1 & 2 & -2 & 0 \\
& Sub Total & 1 & 3 & -1 & 3
\end{tabular}

$\underline{\text { Total } 3 \text { Chart }}$

$4 \quad 5$

0

9

TABEL IV

HASIL SCORING POLIGRAF SUBYEK AY

\begin{tabular}{llrrrr}
\hline \multicolumn{2}{c}{$\begin{array}{c}\text { Grafik } \\
\text { Reaksi Tubuh }\end{array}$} & R1 & R2 & R3 & Total \\
\hline Chart 1 & Pneumo & 0 & 0 & -1 & -1 \\
& EDA & 2 & 2 & -2 & 2 \\
& Cardio/BP & 1 & 0 & 1 & 2 \\
& Sub Total & 3 & 2 & -2 & 3 \\
Chart 2 & Pneumo & 0 & 0 & 0 & 0 \\
& EDA & 2 & -2 & -2 & -2 \\
& Cardio/BP & -1 & -1 & -1 & -3 \\
& Sub Total & 1 & -3 & -3 & -5 \\
Chart 3 & Pneumo & 0 & 0 & 0 & 0 \\
& EDA & -2 & -2 & 2 & -2 \\
& Cardio/BP & -1 & -1 & -1 & -3 \\
Total 3 Chart & 3 & -3 & 1 & -5 \\
& Sub Total & & & & \\
\end{tabular}

TABEL V

HASIL SCORING POLIGRAF SUBYEK WR

\begin{tabular}{llrrrr}
\hline \multicolumn{2}{c}{$\begin{array}{c}\text { Grafik } \\
\text { Reaksi Tubuh }\end{array}$} & R1 & R2 & R3 & Total \\
\hline Chart 1 & Pneumo & 1 & 0 & 0 & 1 \\
& EDA & 2 & -2 & -2 & -2 \\
& Cardio/BP & 1 & -1 & 1 & 1 \\
& Sub Total & 4 & -3 & -1 & 0
\end{tabular}

Chart 2 Pneumo

0

1 0

TABEL VI

HASIL SCORING POLIGRAF SUBYEK NZ

\begin{tabular}{clrrrr}
\hline \multicolumn{2}{c}{$\begin{array}{c}\text { Grafik } \\
\text { Reaksi Tubuh }\end{array}$} & R1 & R2 & R3 & Total \\
\hline Chart 1 & Pneumo & 0 & 0 & 0 & 0 \\
& EDA & -2 & -2 & 2 & -2 \\
& Cardio/BP & -1 & -1 & 1 & -1 \\
& Sub Total & -3 & -3 & 3 & -3 \\
Chart 2 & Pneumo & 0 & 0 & 0 & 0 \\
& EDA & 2 & -2 & 2 & 2 \\
& Cardio/BP & 1 & 0 & -1 & 0 \\
& Sub Total & 3 & -2 & 1 & 2 \\
Chart 3 & Pneumo & 0 & 0 & 0 & 0 \\
& EDA & -2 & -2 & 2 & -2 \\
& Cardio/BP & -1 & -1 & 0 & -2 \\
& Sub Total & 3 & -3 & 2 & -4
\end{tabular}

\begin{tabular}{lllll} 
Total 3 Chart & 3 & -8 & 6 & -5 \\
\hline
\end{tabular}

Nilai total 3 chart poligraf (Pneumo, EDA, Cardio/BP), dari masing-masing subyek terlihat pada Tabel I - Tabel VI didapatkan subyek Ag dengan nilai total +3 adalah NDI (jujur), subyek Yog dengan nilai total +6 adalah NDI (jujur), subyek Erk dengan nilai total +9 adalah NDI (jujur), subyek Ay dengan nilai total -7 adalah DI (bohong), subyek $\mathrm{Wr}$ dengan nilai total +5 adalah NDI (jujur) dan subyek $\mathrm{Nz}$ dengan nilai total -5 adalah DI (bohong).

\subsection{Hasil analisis statistik fitur fonetik akustik}

Analisis ini berdasarkan kalkulasi statistik nilai data kelompok formant, intensity dan pitch. Oleh karena kelompok data formant, intensity dan pitch bersumber dari 1 subyek, maka kelompok data tersebut merupakan kelompok data yang saling berhubungan. Untuk data yang saling berhubungan, jika kelompok data sampel bertipe interval atau rasio, serta distribusi datanya mengikuti distribusi normal (berlaku untuk kedua kelompok data) maka uji statistik yang digunakan adalah jenis uji parametrik, yaitu Uji $T$ Paired untuk menentukan ada tidaknya perbedaan rata-rata dua kelompok data tersebut. Tapi jika distribusi data tidak mengikuti distribusi normal (kedua kelompok data atau salah satu tidak berdistribusi normal) maka uji statistik yang digunakan adalah jenis uji non parametrik, yaitu Uji Wilcoxon.

Adapun Uji Normalitas yang digunakan adalah Uji Kolmogorov-Smirnov bila sampel lebih besar dari 50 dan Uji Shapiro-Wilk bila sampel lebih kecil dari 50 [23].

Anang Kusnadi: Deteksi Kebohongan berdasarkan Fitur Fonetik ... 
Pengambilan keputusannya jika Sig > 0,05 maka data berdistribusi normal, jika Sig $<0,05$ maka data tidak berdistribusi normal.

Untuk analisis stastistik terhadap sampel suara jawaban "tidak" dari pertanyaan comparison $(\mathrm{C} 1, \mathrm{C} 2, \mathrm{C} 3)$ dan relevant $(R 1, R 2, R 3)$ pada tes poligraf dilakukan 3 kali pengulangan tes poligraf, dengan formulasi sebagai berikut :

TABEL VII

FORMULASI UJI

\begin{tabular}{|c|c|c|c|}
\hline Sampel Suara & & Statis & \\
\hline Tes1 (Chart1) & C1R1 & C2R2 & C3R3 \\
\hline Tes2 (Chart 2) & C3R2 & C1R3 & C2R1 \\
\hline Tes3 (Chart 3) & C2R3 & C3R1 & C1R2 \\
\hline
\end{tabular}

Contoh sampel suara yang dianalisis adalah dari subyek Ag Chart1 pasangan uji C1R1 (pada tes 1). Apakah ada perbedaan nilai formant, intensity dan pitch antara jawaban "Tidak" pertanyaan comparison C1 dengan jawaban "Tidak" pertanyaan relevant R1 subyek Ag? Adapun hasil analisis kalkulasi statistik nilai formant, intensity dan pitch subyek Ag pasangan uji C1R1 berikut ini.

\subsubsection{Analisis Formant $(\mathrm{Hz})$}

Dari pengamatan penulis untuk fitur formant dari 5 formant F1, F2, F3, F4, F5 hanya 3 formant yang signifikan untuk dianalisis yaitu F1, F2 dan F3. Mulai dengan menguji distribusi normal kedua kelompak data pasangan uji $\mathrm{C} 1$ dan R1. Adapun hasil Uji Normalitas formant $(\mathrm{Hz})$ subyek $\mathrm{Ag}$ Chart 1 C1R1 dapat dilihat pada Tabel VIII

TABEL VIII

Uji NORMALITAS FORMANT (Hz) SUBYEK AG CHART 1 C1R1

\begin{tabular}{llr|r|r|r|r|r}
\hline & \multicolumn{4}{c}{ Kolmogorov-Smirnov $^{\boldsymbol{a}}$} & \multicolumn{3}{c}{ Shapiro-Wilk } \\
& Kelas & Statistik & \multicolumn{1}{c}{ df } & \multicolumn{1}{c}{ Sig. } & Statistik & df & Sig. \\
\hline F1 & C1 & 0,225 & 65 & 0,000 & 0,830 & 65 & 0,000 \\
\hline & R1 & 0,384 & 49 & 0,000 & 0,646 & 49 & 0,000 \\
\hline F2 & C1 & 0,201 & 65 & 0,000 & 0,833 & 65 & 0,000 \\
\hline & R1 & 0,189 & 49 & 0,000 & 0,861 & 49 & 0,000 \\
\hline F3 & C1 & 0,074 & 65 & 0,200 & 0,969 & 65 & 0,102 \\
\hline & R1 & 0,181 & 49 & 0,000 & 0,927 & 49 & 0,005 \\
\hline
\end{tabular}

a. Lilliefors Significance Correction

Dari Uji Normalitas diperoleh hasil nilai Sig data F1 untuk C1, R1 adalah 0,000 maka Sig $<0,05$, sehingga data tidak berdistribusi normal, Sig data F2 untuk C1, R1 adalah 0,000, maka Sig < 0,05, sehingga data tidak berdistribusi normal, Sig data F3 untuk C1 adalah 0,200 maka Sig > 0,05, sehingga data berdistribusi normal dan R1 adalah 0,005, maka Sig < 0,05, sehingga data tidak berdistribusi normal. Dipresentasikan dengan histogram pada gambar 5 .
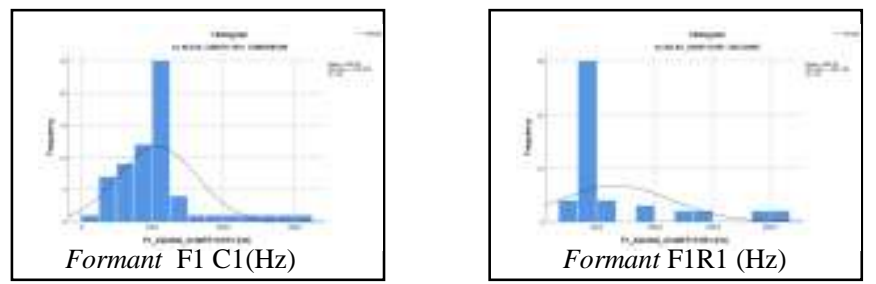
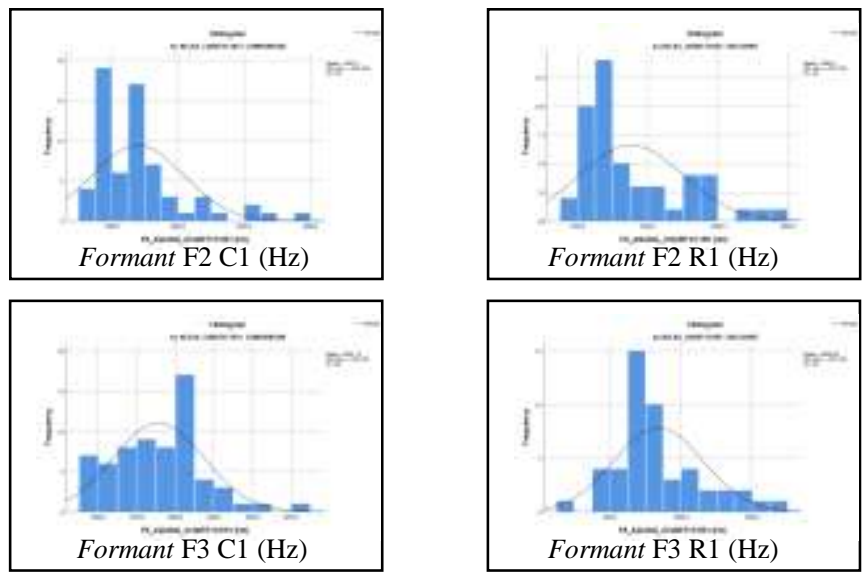

Gambar 5 : Histogram Formant $(\mathrm{Hz})$ subyek Ag Chart 1 C1R1

Hasil Uji Normalitas formant Ag Chart 1 C1R1 menunjukkan bahwa Sig data formant (F1, F2 dan F3) jawaban kata "tidak" pada pasangan uji $\mathrm{C} 1$ maupun $\mathrm{R} 1$, keduanya atau salah satu data tidak berdistribusi normal, sehingga digunakan Uji Wilcoxon untuk uji beda formant pasangan uji C1R1. Hasil Uji Wilcoxon dapat dilihat pada Tabel IX.

TABEL IX

HASIl Uji WILCOXON Formant (Hz) SUBYEK Ag CHART 1 C1R1

Test Statistics ${ }^{a}$

F1_Ag $\quad$ F2_Ag $\quad$ F3_Ag

Chart1 R1 Chart1 R1 Chart1 R1

(Hz) - $\quad(\mathrm{Hz})$ - $\quad(\mathrm{Hz})$ -

F1_Ag_ F2_Ag_ F3_Ag

\begin{tabular}{l|l|l} 
Chart1 C1 & Chart1 C1 & Chart1 C1
\end{tabular}

\begin{tabular}{l|l|l}
$(\mathbf{H z})$ & $(\mathbf{H z})$ & $(\mathbf{H z})$ \\
\hline
\end{tabular}

\begin{tabular}{|lr|r|r}
\hline Z & $-0,661^{\mathrm{b}}$ & $-2,074^{\mathrm{b}}$ & $-1,825^{\mathrm{c}}$ \\
\hline Asymp. Sig. (2- & 0,508 & 0,038 & 0,068
\end{tabular}

tailed)

a. Wilcoxon Signed Ranks Test

b. Based on negative ranks.

c. Based on positive ranks.

Dari Uji Wilcoxon Formant Ag Chart 1 C1R1, diperoleh nilai Sig F1 adalah 0,508 dan Sig F3 adalah 0,068 maka Sig > 0,05, sehingga Ho diterima, berarti tidak ada perbedaan nilai Formant jawaban kata "tidak" $\mathrm{C} 1$ dengan jawaban kata "tidak" R1 pada F1 dan F3. Untuk Sig F2 adalah 0,038, maka Sig < 0,05, sehingga Ho ditolak, berarti ada perbedaan nilai Formant jawaban kata "tidak" C1 dengan jawaban kata "tidak" R1 pada F2.

\subsubsection{Analisis intensity $(\mathrm{dB})$}

Hasil Uji Normalitas intensity (dB) subyek Ag Chart 1 C1R1 dapat dilihat pada Tabel X

TABEL $X$

UJi NORMALITAS INTENSITY (DB) SUBYEK Ag CHART 1 C1R1

\begin{tabular}{lc|c|r|r|r|r}
\hline Kolmogorov-Smirnov & \multicolumn{4}{c}{ Shapiro-Wilk } \\
Kelas & Statistik & df & Sig. & Statistik & df & Sig. \\
\hline C1 & 0,156 & 38 & 0,020 & 0,910 & 38 & 0,005 \\
\hline R1 & 0,164 & 29 & 0,046 & 0,909 & 29 & 0,016 \\
\hline a. Lilliefors Significance Correction
\end{tabular}


Sig data intensity untuk $\mathrm{C} 1$ adalah 0,005 dan R1 adalah 0,016 maka Sig $<0,05$, sehingga data tidak berdistribusi normal. Dipresentasikan dengan histogram pada gambar 6.
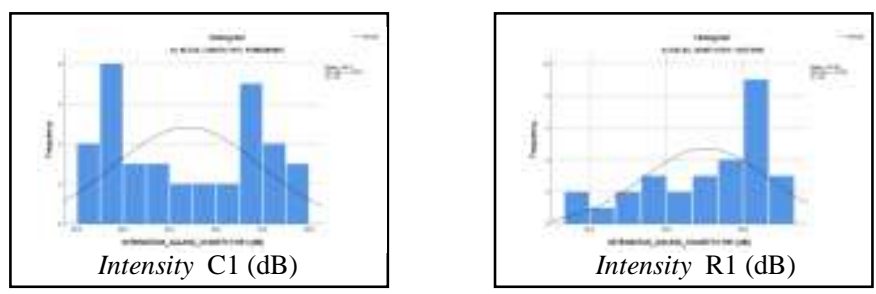

Gambar 6 : Histogram distribusi data Intensity (dB) subyek Ag Chart 1 C1R1

Hasil Uji Normalitas intensity jawaban kata "tidak" Ag Chart 1 C1R1, baik C1 maupun R1, keduanya tidak berdistribusi normal, maka digunakan Uji Wilcoxon untuk uji beda intensity pasangan uji C1R1. Hasil uji Wilcoxon dapat dilihat pada Tabel XI

TABEL XI

Hasil Uji Wilcoxon INTENSITY (DB) SUbYeK AG CHART 1 C1R1

\begin{tabular}{|c|c|}
\hline \multicolumn{2}{|c|}{ Test Statistics ${ }^{a}$} \\
\hline & $\begin{array}{l}\text { Intensity_Ag_Chart1 R1 (dB) - } \\
\text { Intensity_Ag_Chart1 C1 (dB) }\end{array}$ \\
\hline $\mathrm{Z}$ & $-4,703 b$ \\
\hline Asymp. Sig. (2-tailed) & 0,000 \\
\hline
\end{tabular}

Dari Uji Wilcoxon diperoleh nilai Sig intensity Ag Chart 1 C1R1 adalah 0,000 maka Sig < 0,05, sehingga Ho ditolak, berarti ada perbedaan nilai intensity jawaban kata "tidak" $\mathrm{C} 1$ dengan jawaban kata "tidak" R1.

\subsubsection{Analisis Pitch $(\mathrm{Hz})$}

Hasil Uji Normalitas pitch $(\mathrm{Hz})$ subyek Ag Chart 1 C1R1 dapat dilihat pada Tabel XII.

TABEL XII

Uji Normalitas PITCH (DB) SubyeK Ag CHART 1 C1R1

\begin{tabular}{lr|r|r|r|r|r}
\hline & \multicolumn{2}{c}{ Kolmogorov-Smirnov } & \multicolumn{3}{c}{ Shapiro-Wilk } \\
Kelas & Statistik & \multicolumn{1}{c}{ df } & \multicolumn{1}{c}{ Sig. } & Statistik & df & \multicolumn{1}{c}{ Sig. } \\
\hline C1 & 0,268 & 16 & 0,003 & 0,820 & 16 & 0,005 \\
\hline R1 & 0,332 & 23 & 0,000 & 0,758 & 23 & 0,000 \\
\hline
\end{tabular}

a. Lilliefors Significance Correction

Dari Uji Normalitas diperoleh nilai Sig data pitch untuk C1 adalah 0,005 dan R1 adalah 0,000 maka Sig < 0,05, sehingga data tidak berdistribusi normal. Dipresentasikan dengan histogram pada gambar 7 .

Anang Kusnadi: Deteksi Kebohongan berdasarkan Fitur Fonetik ...
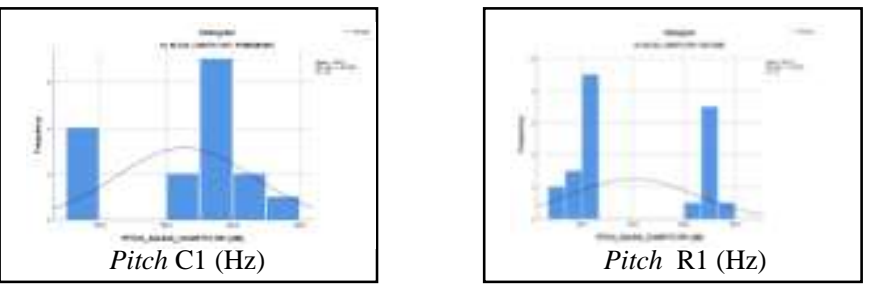

Gambar 7 : Histogram distribusi data Pitch $(\mathrm{Hz})$ subyek Ag Chart 1 C1R1

Hasil Uji Normalitas pitch jawaban kata "tidak" Ag Chart 1 C1R1, menunjukkan bahwa data pitch pada pasangan uji $\mathrm{C} 1$ maupun R1, keduanya tidak berdistribusi normal, maka digunakan Uji Wilcoxon untuk uji beda Pitch pasangan uji C1R1. Hasil Uji Wilcoxon dapat dilihat pada Tabel XIII

TABEL XIII

Hasil Uji Wilcoxon PITCH (DB) SUBYeK Ag CHART 1 C1R1

Test Statistics ${ }^{a}$

Pitch_Ag_Chart1 R1 (Hz) -

Pitch_Ag_Chart1 C1 (Hz)

\begin{tabular}{lc}
\hline $\mathrm{Z}$ & Pitch_Ag_Chart1 C1(Hz) \\
\hline Asymp. Sig. (2-tailed) & $-2,379^{\mathrm{b}}$ \\
\hline a. Wilcoxon Signed Ranks Test & 0,017 \\
b. Based on negative ranks. &
\end{tabular}

Dari Uji Wilcoxon diperoleh nilai Sig pitch Ag Chart 1 C1R1 adalah 0,017 maka Sig < 0,05, sehingga Ho ditolak, berarti ada perbedaan nilai pitch jawaban kata "tidak" C1 dengan jawaban kata "tidak" R1.

Kemudian analisis statistik nilai formant, intensity dan pitch dilanjutkan terhadap pasangan uji lain pada tes 1 , tes 2 dan tes 3 sampel suara subyek Ag. Dan juga terhadap sampel suara 5 subyek lainnya yaitu Yog, Erk, Ay, Wr dan Nz. Berdasarkan hasil analisis statistik kemudian dilakukan penilaian/scoring untuk menguji kebohongan berdasarkan fitur fonetik akustik. Berdasarkan analisis statistik terhadap sampel suara subyek terperiksa, maka didapatkan hasil scoring uji kebohongan yang dituangkan dalam tabel-tabel berikut ini.

TABEL XIV

HASIL SCORING FITUR FORMANT SUBYEK Ag UNTUK JAWABAN KATA “TIDAK” PADA PEMERIKSAAN POLIGRAF

\begin{tabular}{rlrrrr}
\hline \multirow{2}{*}{ Tes } & \multicolumn{1}{c}{$\begin{array}{c}\text { Pasangan } \\
\text { Uji }\end{array}$} & F1 & F2 & F3 & Total \\
\hline Chart 1 & C1R1 & 1 & -1 & 1 & 1 \\
& C2R2 & -1 & -1 & -1 & -3 \\
& C3R3 & 1 & 1 & 1 & 3 \\
& Sub Total & 1 & -1 & -1 & -1 \\
Chart 2 & C3R2 & -1 & 1 & 1 & 1 \\
& C1R3 & 1 & 1 & 1 & 3 \\
& C2R1 & 1 & 1 & -1 & 1 \\
& Sub Total & 1 & 3 & 1 & 5 \\
& & & & & \\
Chart 3 & C2R3 & 1 & -1 & 1 & 1 \\
& C3R1 & 1 & 1 & -1 & 1 \\
\hline
\end{tabular}

p-ISSN:1693 - 2951; e-ISSN: 2503-2372 


\begin{tabular}{|c|c|c|c|c|c|}
\hline & C1R2 & 1 & -1 & -1 & -1 \\
\hline & Sub Total & 3 & -1 & -1 & 1 \\
\hline \multicolumn{2}{|c|}{ Total 3 Chart } & 5 & 1 & -1 & 5 \\
\hline \multicolumn{6}{|c|}{$\begin{array}{c}\text { TABEL XV } \\
\text { HASIL SCORING FITUR FORMANT SUBYEK YOG UNTUK JAWABAN KATA } \\
\text { "TIDAK" PADA PEMERIKSAAN POLIGRAF }\end{array}$} \\
\hline \multirow{2}{*}{ Tes } & \multirow{2}{*}{$\begin{array}{c}\text { Pasangan } \\
\text { Uji }\end{array}$} & \multicolumn{3}{|c|}{ Skor } & \multirow{2}{*}{ Total } \\
\hline & & F1 & F2 & F3 & \\
\hline \multirow[t]{5}{*}{ Chart 1} & C1R1 & -1 & -1 & -1 & -3 \\
\hline & $\mathrm{C} 2 \mathrm{R} 2$ & 1 & -1 & -1 & -1 \\
\hline & C3R3 & -1 & 1 & -1 & -1 \\
\hline & Sub & & & & \\
\hline & Total & -1 & -1 & -3 & -5 \\
\hline \multirow[t]{5}{*}{ Chart 2} & $\mathrm{C} 3 \mathrm{R} 2$ & 1 & -1 & -1 & -1 \\
\hline & C1R3 & 1 & 1 & 1 & 3 \\
\hline & $\mathrm{C} 2 \mathrm{R} 1$ & 1 & 1 & -1 & 1 \\
\hline & Sub & & & & \\
\hline & Total & 3 & 1 & -1 & 3 \\
\hline \multirow[t]{5}{*}{ Chart 3} & $\mathrm{C} 2 \mathrm{R} 3$ & -1 & 1 & -1 & -1 \\
\hline & C3R1 & -1 & 1 & -1 & -1 \\
\hline & C1R2 & -1 & 1 & 1 & 1 \\
\hline & Sub & & & & \\
\hline & Total & -3 & 3 & -1 & -1 \\
\hline \multicolumn{2}{|c|}{ Total 3 Chart } & -1 & 3 & -5 & -3 \\
\hline
\end{tabular}

TABEL XVI
HASIL SCORING FITUR FORMANT SUBYEK ERK UNTUK JAWABAN KATA
"TIDAK" PADA PEMERIKSAAN POLIGRAF

\begin{tabular}{clrrrr}
\hline \multirow{2}{*}{ Tes } & $\begin{array}{c}\text { Pasangan } \\
\text { Uji }\end{array}$ & \multicolumn{5}{c}{ F1 } & $\begin{array}{c}\text { Skor } \\
\text { F2 }\end{array}$ & \multicolumn{1}{c}{ F3 } & Total \\
\hline Chart 1 & C1R1 & -1 & 1 & 1 & 1 \\
& C2R2 & -1 & 1 & -1 & -1 \\
& C3R3 & -1 & -1 & -1 & -3 \\
& Sub & & & & \\
& Total & -3 & 1 & -1 & -3
\end{tabular}

$\begin{array}{clrrrr}\text { Chart } 2 & \text { C3R2 } & 1 & -1 & 1 & 1 \\ & \text { C1R3 } & 1 & 1 & -1 & 1 \\ & \text { C2R1 } & 1 & -1 & 1 & 1 \\ & \text { Sub } & & & & \\ \text { Total } & 3 & -1 & 1 & 3\end{array}$

$\begin{array}{rlrrrr}\text { Chart } 3 & \text { C2R3 } & 1 & -1 & -1 & -1 \\ & \text { C3R1 } & 1 & 1 & 1 & 3 \\ \text { C1R2 } & 1 & 1 & 1 & 3 \\ & \text { Sub } & & & & \\ \text { Total } & 3 & 1 & 1 & 5\end{array}$

Total 3 Chart 3

TABEL XVII

HASIl SCORING FITUR FORMANT SUBYEK Ay UNTUK JAWABAN KATA "TIDAK" PADA PEMERIKSAAN POLIGRAF

\begin{tabular}{llcccc}
\hline \multirow{2}{*}{ Tes } & $\begin{array}{c}\text { Pasangan } \\
\text { Uji }\end{array}$ & F1 & $\begin{array}{c}\text { Skor } \\
\text { F2 }\end{array}$ & F3 & Total \\
\hline Chart 1 & C1R1 & 1 & -1 & 1 & 1 \\
& C2R2 & -1 & -1 & -1 & -3 \\
& C3R3 & -1 & -1 & 1 & -1 \\
& Sub Total & -1 & -3 & 1 & -3 \\
\hline
\end{tabular}

Chart $2 \quad$ C3R2

C1R3

C2R1

Sub Total

Chart $3 \quad \mathrm{C} 2 \mathrm{R} 3$

C3R1

C1R2

Sub Total

$\begin{array}{rrrr}1 & -1 & -1 & 1 \\ 1 & -1 & 1 & 1 \\ -1 & 1 & 1 & 1 \\ 1 & -1 & 1 & 1\end{array}$

Total 3 Chart 3

$\begin{array}{rrrr}1 & -1 & -1 & -1 \\ 1 & -1 & -1 & -1 \\ 1 & 1 & -1 & 1 \\ 3 & -1 & -3 & -1\end{array}$

TABEL XVIII

HASIL SCORING FITUR FORMANT SUBYEK Wr UNTUK JAWABAN Kata "TIDAK" PADA PEMERIKSAAN POLIGRAF.

\begin{tabular}{llrrrr}
\hline \multirow{2}{*}{ Tes } & $\begin{array}{l}\text { Pasangan } \\
\text { Uji }\end{array}$ & F1 & $\begin{array}{r}\text { Skor } \\
\text { F2 }\end{array}$ & F3 & Total \\
\hline Chart 1 & C1R1 & 1 & 1 & -1 & 1 \\
& C2R2 & -1 & -1 & 1 & -1 \\
& C3R3 & 1 & 1 & 1 & 3 \\
& Sub Total & 1 & 1 & 1 & 3 \\
Chart 2 & C3R2 & 1 & 1 & -1 & 1 \\
& C1R3 & 1 & -1 & -1 & -1 \\
& C2R1 & 1 & -1 & -1 & -1 \\
& Sub Total & 3 & -1 & -3 & -1 \\
Chart 3 & C2R3 & 1 & -1 & -1 & -1 \\
& C3R1 & -1 & 1 & 1 & 1 \\
& C1R2 & -1 & 1 & 1 & 1 \\
& Sub Total & -1 & 1 & 1 & 1 \\
\multicolumn{1}{c}{ Total 3 Chart } & & & & \\
\hline
\end{tabular}

TABEL XIX

HASIl SCORING Fitur Formant SUbyek NZ Untuk Jawaban Kata "TidaK” PADA PEMERIKSAAN POLIGRAF

\begin{tabular}{llcccc}
\hline \multirow{2}{*}{ Tes } & $\begin{array}{l}\text { Pasangan } \\
\text { Uji }\end{array}$ & F1 & $\begin{array}{r}\text { Skor } \\
\text { F2 }\end{array}$ & F3 & Total \\
\hline Chart 1 & C1R1 & -1 & -1 & -1 & -3 \\
& C2R2 & 1 & -1 & -1 & -1 \\
& C3R3 & -1 & -1 & 1 & -1 \\
& Sub Total & -1 & -3 & -1 & -5 \\
Chart 2 & C3R2 & 1 & -1 & -1 & -1 \\
& C1R3 & -1 & -1 & -1 & -3 \\
& C2R1 & -1 & 1 & 1 & 1 \\
& Sub Total & -1 & -1 & -1 & -3 \\
\multirow{5}{*}{ Chart 3 } & C2R3 & 1 & -1 & -1 & -1 \\
& C3R1 & -1 & -1 & -1 & -3 \\
& C1R2 & -1 & -1 & -1 & -3 \\
& Sub Total & -1 & -3 & -3 & -7
\end{tabular}

Total 3 Chart $-3$

TABEL XX

HASIL SCORING FITUR INTENSITY SUBYEK TERPERIKSA UNTUK JAWABAN Kata "TidAK” PadA PEMERIKSAAn PoligraF

\begin{tabular}{cccccccc}
\hline \multirow{2}{*}{ Tes } & Pasangan & \multicolumn{6}{c}{ Skor } \\
& Uji & Ag & Yog & Erk & Ay & Wr & Nz \\
\hline Chart 1 & C1R1 & -1 & -1 & 1 & 1 & -1 & -1 \\
& C2R2 & -1 & -1 & 1 & 1 & 1 & 1
\end{tabular}




\begin{tabular}{clrrrrrr} 
& C3R3 & -1 & 1 & 1 & -1 & 1 & -1 \\
& Sub Total & -3 & -1 & 3 & 1 & 1 & -1 \\
Chart 2 & C3R2 & -1 & -1 & 1 & 1 & 1 & -1 \\
& C1R3 & 1 & 1 & -1 & -1 & 1 & 1 \\
& C2R1 & 1 & -1 & -1 & -1 & 1 & -1 \\
& Sub Total & 1 & -1 & -1 & -1 & 3 & -1 \\
Chart 3 & C2R3 & 1 & 1 & -1 & -1 & 1 & 1 \\
& C3R1 & 1 & -1 & 1 & 1 & -1 & 1 \\
& C1R2 & -1 & 1 & 1 & -1 & 1 & 1 \\
& Sub Total & 1 & 1 & 1 & -1 & 1 & 3 \\
Total 3 Chart & -1 & -1 & 3 & -1 & 5 & 1 \\
\hline
\end{tabular}

TABEL XXI

HASIL SCORING FITUR PITCH SUBYEK TERPERIKSA UNTUK JAWABAN KATA "TIDAK" PADA PEMERIKSAAN POLIGRAF

\begin{tabular}{clrrrrrr}
\hline \multirow{2}{*}{ Tes } & $\begin{array}{l}\text { Pasangan } \\
\text { Uji }\end{array}$ & Ag & Yog & Erk & Ay & Wr & Nz \\
\hline Chart 1 & C1R1 & -1 & -1 & 1 & 1 & 1 & -1 \\
& C2R2 & 1 & 1 & -1 & -1 & -1 & -1 \\
& C3R3 & 1 & 1 & 1 & 1 & -1 & -1 \\
& Sub Total & 1 & 1 & 1 & 1 & -1 & -3 \\
Chart 2 & C3R2 & 1 & -1 & 1 & 1 & -1 & -1 \\
& C1R3 & 1 & 1 & -1 & -1 & -1 & 1 \\
& C2R1 & -1 & -1 & -1 & 1 & -1 & -1 \\
& Sub Total & 1 & -1 & -1 & 1 & -3 & -1 \\
Chart 3 & C2R3 & 1 & -1 & -1 & 1 & 1 & 1 \\
& C3R1 & 1 & 1 & -1 & -1 & 1 & -1 \\
& C1R2 & 1 & -1 & 1 & -1 & 1 & 1 \\
& Sub Total & 3 & -1 & -1 & -1 & 3 & 1 \\
Total 3 Chart & & & -1 & -1 & 1 & -1 & 3 \\
\hline
\end{tabular}

\subsection{Pembahasan}

Dari keterangan seluruh subyek terperiksa setelah tahap tes poligraf dan perekaman sampel suara selesai maka diketahui bahwa kelompok control atau kelompok yang jujur adalah subyek Ag, Erk dan Wr, sedangkan kelompok treatment atau kelompok bohong adalah subyek Yog, Ay dan Nz. Keterangan masing-masing subyek terperiksa dalam penelitian ini dipakai sebagai acuan/pembanding untuk evaluasi scoring/penilaian deteksi kebohongan dengan tes poligraf maupun deteksi kebohongan berdasarkan fitur fonetik akustik.

Berdasarkan nilai total kalkulasi statistik fitur fonetik akustik subyek terperiksa untuk jawaban kata "tidak" pada pemeriksaan poligraf (lihat Tabel XXII) dan dengan berpedoman pada penetapan skor total $(+)$ adalah terindikasi jujur dan skor total (-) adalah terindikasi bohong, maka diperoleh hasil untuk fitur formant, skor total subyek $\mathrm{Ag}$ dengan nilai +5 adalah NDI (jujur), subyek Yog dengan nilai total -3 adalah DI (bohong), subyek Erk dengan nilai total +5 adalah NDI (jujur), subyek Ay dengan nilai total -3 adalah DI (bohong), subyek Wr dengan nilai total +3 adalah NDI (jujur) dan subyek $\mathrm{Nz}$ dengan nilai total -15 adalah DI (bohong). Anang Kusnadi: Deteksi Kebohongan berdasarkan Fitur Fonetik ...
Hasil ini berkorelasi signifikan, mempunyai probabilitas keberhasilan mendeteksi kebohongan adalah $100 \%$,

Untuk fitur intensity, skor total subyek Ag dengan nilai total -1 adalah DI (bohong), subyek Yog dengan nilai total -1 adalah DI (bohong), subyek Erk dengan nilai total +3 adalah NDI (jujur), subyek Ay dengan nilai total -1 adalah DI (bohong), subyek Wr dengan nilai total +5 adalah NDI (jujur) dan subyek Nz dengan nilai total +1 adalah NDI (jujur), hasil ini kurang signifikan, mempunyai probabilitas keberhasilan mendeteksi kebohongan adalah 66,666\%.

Untuk fitur pitch skor total subyek Ag dengan nilai total +5 adalah NDI (jujur), subyek Yog dengan nilai total -1 adalah DI (bohong), subyek Erk dengan nilai total -1 adalah DI (bohong), subyek Ay dengan nilai total +1 adalah NDI (jujur), subyek Wr dengan nilai total -1 adalah DI (bohong) dan subyek Nz dengan nilai total +3 adalah NDI (jujur), hasil ini kurang signifikan, mempunyai probabilitas keberhasilan mendeteksi kebohongan adalah 33,333\%.

TABEL XXII

HASIL SCORING FONETIK AKUSTIK SUBYEK TERPERIKSA UNTUK JAWABAN Kata “TidAK” PADA PEMERIKSAAN POLIGRAF

\begin{tabular}{lcccccc}
\hline \multicolumn{1}{c}{ Fitur } & Ag & Yog & Erk & Ay & Wr & Nz \\
\hline Formant & 5 & -3 & 5 & -3 & 3 & -15 \\
Intensity & -1 & -1 & 3 & -1 & 5 & 1 \\
Pitch & 5 & -1 & -1 & 1 & -1 & 3 \\
\hline
\end{tabular}

Berdasarkan hasil di atas dapat dikatakan bahwa fitur formant berkorelasi signifikan dan digunakan sebagai fitur fonetik akustik untuk mendeteksi kebohongan, sedangkan intensity maupun pitch kurang signifikan untuk mendeteksi kebohongan.

TABEL XXIII

HASIL TES POLIGRAF VS FITUR FORMANT

\begin{tabular}{lllllll}
\hline \multicolumn{1}{c}{ Tes } & Ag & Yog & Erk & Ay & Wr & \multicolumn{1}{c}{ Nz } \\
\hline $\begin{array}{l}\text { Acuan/pengakuan } \\
\text { subyek }\end{array}$ & NDI & DI & NDI & DI & NDI & DI \\
Tes poligraf & NDI & NDI & NDI & DI & NDI & DI \\
Kesimpulan & True & False & True & True & True & True \\
& Positif & Positif & Positif & Negatif & Positif & Negatif \\
Fitur formant & NDI & DI & NDI & DI & NDI & DI \\
Kesimpulan & True & True & True & True & True & True \\
& Positif & Negatif & Positif & Negatif & Positif & Negatif \\
\hline
\end{tabular}

Pada Tabel XXIII menunjukkan bahwa Probabilitas keberhasilan Tes poligraf dalam mendeteksi kebohongan adalah 83,333\% persen mampu menjawab benar, sedangkan probabilitas keberhasilan deteksi kebohongan berdasarkan fitur fonetik akustik formant adalah $100 \%$ mampu menjawab benar.

\section{SIMPULAN}

Penelitian ini bertujuan untuk melakukan penyelidikan awal dalam usaha untuk mengetahui adanya hubungan p-ISSN:1693 - 2951; e-ISSN: 2503-2372 
beberapa fitur fonetik akustik dengan kebohongan seseorang. Fitur-fitur yang diteliti tersebut adalah, formant, intensity dan pitch. Sejauh ini data yang dianalisis secara statistik menunjukkan adanya korelasi antara fitur fonetik akustik dengan kondisi seseorang berbohong atau tidak berbohong. Fitur formant diketahui sangat signifikan untuk mendeteksi kebohongan seseorang, karena dalam penelitian ini mempunyai probabilitas keberhasilan mendeteksi kebohongan $100 \%$, sedangkan untuk fitur intensity dan pitch kurang signifikan dipakai untuk mendeteksi kebohongan karena hanya mempunyai probabilitas keberhasilan mendeteksi kebohongan 66,666\%. dan 33,333\%. Metode tes poligraf juga mempunyai probabilitas keberhasilan mendeteksi kebohongan yang cukup baik yaitu 83,333\%.

Bahwa penelitian ini adalah merupakan awal dari penelitian yang lebih besar berkaitan dengan metode deteksi kebohongan, utamanya deteksi kebohongan berdasarkan fonetik akustik. Hasil penelitian ini diharapkan dapat memperkuat pemeriksaan poligraf dalam meningkatkan probabilitas mendeteksi kebohongan. Penulis berharap dimasa mendatang dapat melakukan penelitian dengan sampel yang lebih banyak dan dengan subyek yang benar-benar berbohong dalam kasus nyata. ini pastinya akan lebih memberikan pengaruh signifikan secara menyeluruh terhadap kondisi berbohong dan tidak berbohong dalam domain suara.

Penelitian lebih lanjut yang diusulkan adalah peningkatan kinerja deteksi kebohongan berdasarkan fonetik akustik dengan perangkat berbasis mesin, tentunya setelah benar-benar didapatkan karakteristik fitur fonetik akustik yag representative untuk kondisi berbohong atau tidak berbohong seseorang.

\section{DAFTAR PUSTAKA}

[1] Guozhen An, 2015. "Literature Review For Deception Detection", A Second Exam submitted to the Graduate Faculty in Computer Science in partial fulllment of the requirements for the degree of Doctor of Philosophy, The City University of New York.

[2] Neeraj Bhagel, dkk., August 2020. "Truth Identification From EEG Signal By Using Convolution Neural Network : Lie Detection”, IEEE. DOI: 10.1109/TSP49548.2020.9163497.

[3] M. Ashadur Rahman, dkk., January 2017. "Lie Detection From Fnir Signal And Neuro Image”, IEEE. DOI: 10.1109/ICTEA.2012.6462897.

[4] R. Cakmak, Akram M. Zeki, April 2015. "Neuro Signal Based Lie Detection”, IEEE. DOI: 10.1109/IRIS.2015.7451606.

[5] Birender Singh, dkk., November 2015. "Lie Detection Using Image Processing”, IEEE.DOI: 10.1109/ICACCS.2015.7324092.

[6] A. Freire, M. Eskritt, and K. Lee, 2004 "Are Eyes Windows To A Deceiver's Soul? Children's Use Of Another's Eye Gaze Cues In A Deceptive Situation", Developmental psychology, vol. 40, no. 6, p. 1093.

[7] Michel Owayjan, dkk., February 2013. "The Design And Development Of A Lie Detection System Using Facial Micro-Expressions", IEEE. DOI: 10.1109/ICTEA.2012.6462897.

[8] D. Matsumoto, H.S. Hwang, Juni. 2011 "Evaluating Truthfulness And Detecting Deception" In press, FBI Law Enforcement Bulletin.

[9] A. Vrij, 2008. "Detecting Lies and Deceit: Pitfalls and Opportunities", Chichester: Wiley.

[10] N. Sebanz and M. Shiffrar, 2009 "Detecting Deception In A Bluffing Body: The Role Of Expertise" Psychonomic bulletin \& review, vol. 16, no. 1, pp. 170-175.

[11] M. Gabela, February 2013. "Evaluation Of The Questions Used In A Polygraph Test", Submitted In Accordance With The Requirements For The Degree Of Magister Technologiae In The Subject Forensic Investigation At The University Of South Africa.

[12] Nelson, dkk., 2011. Using The Empirical Scoring System. Polygraph, 2011, 40 (2).
[13] Charles R. Honts, Juni. 1994 "Psychophysiological Detection Of Deception", Psychological Science, Volume 3 Number 3.

[14] Adler, Michael J., 2009. "Detecting Deceptive Reaksises In Sex Offenders: A Comparison Of Layered Voice Analysis (LVA) And The Polygraph" Working Paper, Counseling and Consultation Services, Inc. Limestone, TN.

[15] Fransisco Lacerda. 2009. "LVA-Technology The Illusion Of Lie Detection" Proceedings Fonetik, Department of Linguistics, Stockholm University.

[16] Hopkins C.S., R. J. Ratley, D. S. Benincasa, J. J. Grieco, 2005 "Evaluation of Voice Stress Analysis Technology" US Air Force Research Laboratory, under contract to the US National Institute for Justice. - Rome, NY, IEEE. DOI: 10.1109/HICSS.2005.254.

[17] Frank Horvath Ph.D. 2002. "The Accuracy Of Auditors And Layered Voice Analysis (LVA) Operators'Judgments Of Truth And Deception During Police Questioning", Journal of Forensic Sciences. Vol. 58, Issue 2.

[18] Christin Kirchhübel \& David M Howard, July 9-14. 2011 "Investigating The Acoustic Characteristics Of Deceptive Speech" Engineering Psychology and Cognitive Ergonomics: 9th International Conference, EPCE 2011, Held as Part of HCI International 2011, Orlando, FL, USA,. Proceedings (pp.28-37).

[19] Savita Sondhi, dkk., 2016. "Voice Analysis For Detection Of Deception Knowledge, Information And Creativity Support Systems (KICSS)", IEEE. DOI: 10.1109/KICSS.2016.7951455.

[20] Nazir, M. 2003. "Metode Penelitian". Jakarta: Ghalia Indonesia.

[21] Dahlan, M.S. 2009. "Statistik untuk Kedokteran dan Kesehatan", Edis 4 (Deskriptif, Bivariat dan Multivariat, dilengkapi Aplikasi dengan Menggunakan SPSS). Jakarta: Salemba Medika.

[22] Idrus Alwi. "Kriteria Empirik Dalam Menentukan Ukuran Sampel Pada Pengujian Hipotesis Statistika Dan Analisis Butir", Jurnal Formatif 2(2): 140-148 ISSN: 2088-351X. 